\title{
Analysis of the impact of social network sites and eWOM marketing, considering the reinforcing dimensions of the concept of luxury, on tendency toward luxury brand
}

\author{
Zahra MajlesiRad $^{1^{*}}$ (ID and Abdol Hamid Haji pour Shoushtari
}

\begin{abstract}
This study, with regard to new ways of marketing in today's digital world, has tried to analyze and evaluate the impact of marketing through social network sites as the most effective electronic word-of-mouth marketing strategy on tendency toward luxury brand or in other words, on purchase intent trigger toward this type of brand. It also outlines that "communication" policy plays a significant role on establishment of strong relationship with customers among luxury marketing mix strategies. The research has been done among users of social network sites that live in the north of Tehran (district nos. 1, 2 and 3). They are considered as social classes A and B, and there is high demand of purchasing luxury brands among them. The impact of structural factors of these sites, as well as demographic factors, with regard to the dimensions that reinforce the concept of "luxury" was studied on the tendency of people toward luxury brands. This study is considered as applied research, and the data collection method is survey-descriptive. The validity of the questionnaire was investigated by exploratory factor analysis through performing principal component analysis. Then the data analysis was conducted by structural equations modeling technique and also Spearman correlation test. At last, most of the hypotheses were confirmed and the results showed a significant impact of social network sites marketing on tendency to luxury brand. The research offers implications for developing effective marketing strategy through social network sites and helps luxury brand managers to build strong customer-brand relationship.
\end{abstract}

Keywords: Social network sites, Electronic word-of-mouth marketing, Luxury brand

\section{Introduction}

As social network sites have become powerful tools in shaping the technological aspect of today's business world, they reinforce the electronic word-of-mouth marketing and quickly affect the purchasing attitude of their customers, potential customers who exchange information over the Internet a portion of their daytime. Social network sites by their systematic structure have provided people with a new way of communicating and sharing contents. Moreover, with regard to the growing

\footnotetext{
*Correspondence: zahra_m.rad@hotmail.com

${ }^{1}$ Faculty of Management, Economics and Accountancy, Payame Noor University, Karaj, Alborz, Iran

Full list of author information is available at the end of the article
}

importance of high demand for luxury brands in the world and rapid change in the luxury marketing strategies, this research will propose a guidance to enhance luxury brands' marketing performance on social network sites and forecast the tendency toward luxury brands whether in shape of making eWOM marketing or in way of, purchase intention.

In fact, nowadays people spend the biggest portion of their income on goods that satisfy more than their necessary or basic human needs [19]. On the other hand, according to Hennig-Thurau et al. [21], electronic wordof-mouth marketing is any positive or negative statement made by actual, potential or former customers about a product or company, to many people and companies 
through the Internet. The growing marketing through social network sites has an increasing influence on people's purchase intention [23].

While in traditional marketing, companies have been trying to establish and communicate with customers through marketing activities such as advertising promoting, direct marketing and sales persons, in recent decades, the managers of luxury brands companies, considering emphasize on the characteristics of luxury brands, have focused on "communication" policy as well as other luxury marketing mix strategies (product, price, distribution) [19].

By expanding the area of social network sites, marketing communications using social network sites are analyzed as business takeoff tools for luxury fashion brands [32]. Now, people can have access to all their required information about brands, especially luxury brands, and flaunt their experiences to others at any time on a social network site. Therefore, considering the power of electronic word-of-mouth interactions, studying the analysis of mentioned impact on tendency toward luxury brand is a must for every communication-based luxury brand company, in order to achieve and also sustain competitive advantage. It is not only a very efficient tool, but also a low risk one due to its low cost.

Today, almost all major social network sites offer luxury brands specialized Web pages for their communication. The implementation of marketing "communications" mix on Internet-based relationship sites is considered in two ways: the interaction with the brand or company and interaction between the users or followers of that page who might be the customers of that luxury brand. Brand pages generally have a huge number of fans, even more than the brand real customers [24]. The interaction between them is called eWOM marketing on a social network site.

According to Klein, Falk, Esch and Gloukhovtsev [33], the creation of positive word of mouth is vital task for luxury brand managers. Social media are ideal tools for eWOM, because customers generate and spread brandrelated information to their friends, peers and other acquaintances without constraints [18].

Also, famous followers or celebrities' credibility is a very strong key to increasing purchase intentions of sustainable luxury goods [7]. In present study, impact of number of "famous followers" on brand pages is a part of research and has been analyzed, as well.

Since the fundamental question of this research is evaluating the tendency of people toward luxury brands on social network sites, the researchers have identified six effective dimensions that reinforce the concept of "luxury" as the basis of analyzing the structural factors of social network sites: (1) rarity, (2) quality, (3) aesthetics,
(4) symbolic meaning, (5) high level of price and (6) extraordinariness [19].

Here are summarized explanations for mentioned features that any luxury brand has.

1. Rarity In contrast to mass market brand, small production volumes and low sales number disclosure

2. Quality The superior everlasting top-of-the-line products

3. Aesthetics A world of beauty and elegance that complies with the taste of the upper class.

4. Symbolic meaning Refers to a large extent to human values and lifestyles.

5. Price The brand offers products which belong to the most expensive products of their category.

6. Extraordinariness It is often much more than necessary and even ordinary [19].

So, the objectives of this research are as follows:

- analysis of the impact of number of "likes" and "shares" of a luxury brand marketing post on a SNS considering feature of "rarity" of a luxury brand, on tendency toward that luxury brand

- analysis of the impact of number of "famous followers" of a luxury brand on relevant brand page at a SNS, on tendency toward that luxury brand

- analysis of the impact of "positive comments" under a luxury brand marketing post on a SNS, considering feature of "quality" of a luxury brand, on tendency toward that luxury brand

- analysis of the impact of "form" of a luxury brand marketing post on a SNS considering feature of "aesthetics" of a luxury brand, on tendency toward that luxury brand

- analysis of the impact of "content" of a luxury brand marketing post on a SNS considering feature of "symbolic meaning" of a luxury brand, on tendency toward that luxury brand

Due to the adaptability of demographic factors such as income level, age and marital status with two features of "price" and "extraordinariness" of a luxury brand, the following objectives were studied as well:

- analysis of the impact of the "income level" of a luxury brand potential customer on their tendency toward luxury brand, considering feature of "price" of a luxury brand

- analysis of the impact of the "age" and "marital status" of a luxury brand potential customer on their tendency toward luxury brand, considering feature of "extraordinariness" of a luxury brand 
It is worth mentioning that the dependent variable "tendency toward luxury brand" or purchase intent trigger is the moment at which the potential customer starts thinking about a purchase that could be triggered by an event, a change in circumstances, a pay rise, a need or even an advertising message [17].

It is a stage following the "awareness" stage in the customer's purchase decision stages. Purchase intent trigger will result in purchase intention, after passing "liking," "preference" and "conviction"; or just, at the same stage an $e$ WOM marketing will be done [23].

The methodology used in present research is surveydescriptive, with the aim of applying in the field of marketing. The study is considered as applied research, in terms of purpose. The type of questionnaire is closed ended or regular and was designed according to 5-point Likert scale. It was prepared following studying relevant marketing references and consulting with marketing professors (see Appendix).

The statistical community was the inhabitants of north areas of Tehran (district nos. 1, 2 and 3). They were customers of luxury brands in the mentioned districts and also active users of social network sites. They were considered as wealthy individuals that would like to convey a sense of social status/prestige, opulence, exclusivity, indulgence and snobbery.

The sample size according to the Cochran formula was 384; after extracting the results of 218 questionnaires on a defined spatial and temporal domain and following acceptable assessment of the reliability of the questionnaire by Cronbach's alpha coefficient, the confirmatory factor analysis technique was used to verify the validity of the structure scale. The data were analyzed in two descriptive and inferential sections, using SPSS 22 and LISREL 9.1. The frequency, percent frequency, averages and standard deviations of main variables were calculated. The research variables had a normal (or near-normal) distribution following skewness and kurtosis tests. In order to describe the validity of questionnaire, principal component analysis was done.

Following testing research objectives by structural equation modeling technique and obtaining standardized coefficients, in order to find the relationship of demographic factors with dependent variable, spearman correlation test was used.

\section{Theoretical background and literature review Luxury brand}

Luxury is a complex and multifaceted term that varies from traditional definitions which refer to "its connection with pleasure and satisfaction of individual feelings through objects or experiences that are more snobbery than ordinary" to new definitions that refer to "its relation to society and the level of culture and the civilization of those people" and is being discussed [41]. The growth of luxury relates to the societal trend that the "rich get richer, and the poor get poorer" [50]. Since the 1980s, the luxury market has grown at about ten percent per year, a much higher rate than the world economy [19]. According to Kapferer and Bastien [29], luxury brands are often influenced by the four following factors: (1) democracy, (2) increased purchasing power, (3) globalization and (4) communications.

Among several confusing definitions of the concept of "luxury," the most well-known description was defined by Dubois et al. [11], and still, the debates on it continue. They characterized luxury by excellent quality, very high price, scarcity and uniqueness, aesthetics and polysensuality, ancestral heritage and personal history, and superfluousness. Other definitions are in ambiguity. For example, Jung Choo et al. [26] quoted that the term is often used to indicate products, services or brands of high price, excellent quality, aesthetic beauty, pleasure or exclusivity or rarity. However, the definitions of Dubois and others were investigated by various researchers from different points of view; as per Kapferer and Bastien [28], most researchers are all agreed that phenomenon of luxury could be analyzed in two respects: social and personal.

Dubois et al. [11] performed a comprehensive study on the perception of consumers on luxury consumption in twenty countries and found out six features of luxury, but it was found a little bit misleading; so, Heine and Phan [20] explained that luxury brands are regarded as images in the minds of customers that comprise associations about six major product-related characteristics (dimensions): rarity, excellent quality, aesthetics, symbolic meaning, high level of price, extraordinariness and overly necessary that can be considered as dimensions ranging from a minimum level that is also necessary for non-luxury brands to a maximum level that corresponds to the highest form of luxury [19].

Although some believe that luxury is to a great extent a highly subjective phenomenon [50], for identifying the frontier of luxury, Sudarsan [47] differentiates the brands according to Kotler's marketing management in five levels along with an example: basic: Kia, utility: Dodge, quality: Infinity, premium: Mercedes and luxury: Rolls-Royce. Then, the degree of luxuriousness is determined by following separation and a representative brand: entry-level luxury brands: Hugo Boss, medium-level luxury brands: D\&G, top-level luxury brands: Louis Vuitton and elitelevel luxury brands: Puiforcat [19]. The last level provides distinctive social prestige to their customers [4].

Among controversial features, regarding the dimension (characteristic) of "aesthetics," Dubois and others 
emphasize the polysensuality of luxury products as they "not only look beautiful but also are (and should be) pleasant to hear, smell, taste or touch" and therefore offer a "source of sensual pleasure" [19]. While Kapferer [27] mentioned that luxury products are held as artistic objects. Art is the aesthetic and social guarantor of luxury: truly a marriage of culture and luxury [25].

Where the distinction between luxury and non-luxury sometimes is blurred, a result of the temptation of luxury brands, the experiential dimension becomes an essential means of identifying true luxury. In this experience, the pleasure provided comes from the stimulation of the senses (smell, taste, sound, visual and touch) [3].

Regarding feature of "symbolic meaning," as per Kapferer and Bastien [28], the DNA of a luxury product is the symbolic desire to belong to a superior class. Luxury brands must represent an emotional meaning for customers when purchasing them, in a way that they think they are buying a personal story from the past [4]. So, the dimension of a symbolic meaning with heritage and history makes the brand stand for "the best from the best for the best"; its charisma fills the room, and regardless of whether it is of a conspicuous or understated nature, deep inside, it is swollen with pride [19]; the high level of prestige and social status apart from any functional utility [24].

The last feature, "extraordinariness," is the main factor differentiating the luxury from the needs. The luxury products do not aim to provide any rational and functional benefit by fulfilling a function; they rather help people realize their dreams by providing emotional and hedonic benefits [4].

All in all, luxury products that are more than necessary and ordinary obviously need to be scarce and cannot be owned by everyone, which is not possible as they are too expensive anyway [51]. Luxury is typically associated with rarity and needs high prices to be credible in terms of higher quality [30].

\section{Marketing mix strategies to enter luxury markets}

Historically, a luxury brand offered a unique store-level experience, and from a customer's perspective, it often involved dressing up and going into a high-end boutique to consult with a salesperson about what to buy. In today's marketplace, however, many luxury firms are attempting to engage luxury customer through the Internet [45]. The marketing of the luxury brands has to give a priority to their long-term strategy and their reputation; they should strictly follow their brand identity that makes them different from each other and from non-luxury brands [29]. In fact, rarity is the key to luxury growth [27].

Luxury marketing mix strategies that partly contradict with the common rules of non-luxury marketing, in order to enter the luxury market and to build a successful luxury brand and to make it remain as a luxury brand, one has to forget the traditional marketing rules. As Bastien and Kapferer [2], anti-laws of luxury brand marketing require an in depth treatment.

Generally, it could be explored through four rules or paradoxes: First the product that emphasizes on quality, packaging, innovation and creativity; second the price that refers to high superlative pricing policy to attract snob customers; third, the distribution policy where the balance between the increasing sales volumes and selective distribution should be maintained. As Fionda and Moore [15], the luxury-specific distribution includes the flagship store; at last, fourth: the communication policy that means controlling the frequency of the emergence of a luxury brand in order to make specific customers aware and prevent raising the public demands $[19,48]$.

One type of marketing communication mix is the use of celebrities or famous individuals and their endorsement in the promotion activities of public relation segment, of course with caution in the luxury strategy to build distinction, style and sustained appeal $[2,19]$. In today's technological world, it is essential to specialize in implementation of new marketing techniques for managing luxury brands.

With the exponential growth of social network sites and various social media, however, luxury brands face challenges in how to maintain brand integrity while harnessing the power of social network sites [1]. The tendency of a customer to stay in a relationship with a brand, beyond cause and effect, usually leads to individual's loyalty to that company and brand, of course under the firm's control which may enhance relationship equity that can be improved through a variety of social tools and to build the images that make customers identify that specialty from among others [32].

The intention to research online and purchase off-line (ROPO) is particularly relevant to luxury brands' products given the high costs of purchasing and the high risks of counterfeit luxury brands online. ROPO in luxury brand consumption can be operationally defined as consumers' behavioral intentions to visit a luxury brand's online channels before making an off-line purchase. Social media can facilitate evaluation through user-generated contents and thus reduce uncertainty and improve efficiency of luxury consumers' online searches [1].

\section{Some previous researches on luxury brands}

Luxury brands have received considerable research interest in marketing literature over the last two decades [44]. Following fast-growing attempts to explain various aspects of luxury brand marketing, Kapferer [27] attracted everyone's attention to the growth of Asian 
luxury markets and defined virtual rarity tactics and also a luxury business model.

Among different studies, an article which conducted by Jung Choo et al. [26], proposed a framework which revealed that the related customer's values of high symbolic, economic and functional of a luxury fashion brand are important for developing a positive relationship with the brand.

Bastien and Kapferer [2] focused on clarifying the luxury product marketing strategies, describing the current situation of the luxury market and the threats and risks of luxury brand marketing.

Wiedmann and Hennigs [50] summarized the luxury marketing management in a handbook, focusing on different approaches to propose a comprehensive framework and then classifying several directions in luxury marketing research.

Freire [16] highlighted the importance of communication of luxury parent Houses on consumers through reinforcing their brand image and attracting more loyal consumers by specific advertisements. The artistic advertisements add the value to the luxury product and the luxury house.

Then, Kapferer and Laurent [30] tried to answer the question where each consumer perceives luxury begins, with consideration that the level varies across consumers and countries. They suggested the researches on luxury should be based on the consumer's own personal definition of the price.

Another research, which has been done by Parguel et al. [42] on price dimension of luxury brand, explored the effect of price display in the premium luxury segment that has a positive influence on luxury perception and then reinforces the brand's perceived quality, uniqueness or conspicuousness.

Koronaki et al. [34] suggested that in order to enhance and maintain the strong relationship with luxury brand customers in today's shifting environment, arts-based initiatives can be designed and implemented as a relationship-strengthening tool for customers.

\section{Electronic word-of-mouth marketing}

Marketing consists of actions taken to build and maintain desirable exchange relationships with target audiences involving a product, service, idea or other object [35].

As markets change, marketing theories must also change to accommodate them. Word-of-mouth marketing is part of a complex cultural process that nonetheless follows an ascertainable pattern; a networked coproduction of marketing messages and meanings; and specially, through newer forums of online community, such as social networking sites [36].
Word-of-mouth marketing is defined as the act of exchanging marketing information among consumers and plays an essential role in changing consumer attitudes and behavior toward products and services. The emergence of Internet-based media has facilitated the development of WOM online, that is, electronic word of mouth.

eWOM in social network sites occurs when consumers provide or search for informal product-related advice through the unique applications of these sites [6].

The perception of brands is influenced through valueenhancing potential of social media campaigns. This new communication channel favors relationship and community building, and it promotes active engagements of consumers. The direct involvement social media enables in respect to the creation of brand value gives consumers ever more power to influence brands [23].

Consumers are likely to seek out other's opinion before making their own purchase decisions. So, online word of mouth has a significant influence on purchase behavior [5].

The above trends have severely diminished the usefulness and practicality of the traditional communications paradigm as a framework for developing integrated marketing communications (IMC) strategies. Social media is a hybrid element of the promotion mix because it combines characteristics of traditional IMC tools (companies talking to customers) with a highly magnified form of word of mouth (customers talking to one another) whereby marketing managers cannot control the content and frequency of such information [38].

In social network sites, opinion seekers may regard recommendations by friends or classmates as credible and reliable, and thus may rely on SNSs as a place to obtain information for their purchases. On the other hand, a socially extensive environment provides opinion leaders with greater opportunities to share product-related thoughts and opinions with other consumers [6].

And also, spreading positive word of mouth is to gain social approval or self-approval by demonstrating their superb purchase decisions. Word-of-mouth communication is an important facilitator of learning and can have a large impact on consumer decisions. Electronic communication, via online consumer review sites, has enabled an immediate information flow to a much wider audience as a single message can affect all site visitors [5].

So, electronic word-of-mouth marketing has a significant impact on all stages of the purchasing behavior of a customer, from pre-awareness to repurchase intent and demonstration of loyalty. eWOM behavior within social network sites may be initiated because of the users' desire to establish and maintain social relationships within their personal networks. By sharing useful product 
information and experience, social network site users can help their social connections (e.g., friends) with purchase-related decisions [6]. On the whole, social media associate eWOM with online consumer-to-consumer interactions about brands [18].

\section{New model for customer path to purchase}

According to Kotler and Armstrong [35], the buyer decision-making process consists of five stages: need recognition, information search, evaluation of alternatives, purchase decision and post-purchase behavior that customer typically passes through them before he purchases. The most well-known and widely applied hierarchy of effects model is AIDA (Attention, Interest, Desire and Action), which consists of the purchase decision or attitude building phases, and another model introduced in the late nineteenth century includes seven phases [23]. Over time, the detail-based look at customer behavior in specialized Internet marketing world showed that the customer path to purchase has been changed a bit. For instance, the modern purchase funnel of Gibson [17], taking into account the emergence of Internet, describes the theoretical decision-making path from the moment of first contact with the brand to the ultimate goal of a purchase and includes post-purchase behavior, as well. The funnel explains what types of content are relevant for the potential customer at each phase [49].

Tendency toward a brand or purchase intent trigger is the moment at which the customer starts thinking about a purchase that could be triggered by an event, a change in circumstances, a pay rise, a need or even an advertising message (see Fig. 1). It will lead to purchase intention, or an eWOM marketing will be made by customer [23].

\section{Some previous researches on electronic word-of-mouth marketing}

De Bruyn and Lilien [9] developed a model to study the influence of unsolicited, electronic referrals within a multistage decision-making framework. They hypothesized and found supporting evidence that tie strength only facilitated awareness, perceptual affinity triggered recipients' interest, and demographically dissimilar ties were more influential than demographically similar ones across different stages of the decision-making process. The study motivated by the challenges facing viral marketing tried to help disentangle the influence of WOM and the antecedents of such influence, at different stages of the decision-making process.

A highly cited article by Kozinets et al. [36] identified four distinct strategic patterns that communicators use and explained that word-of-mouth marketing operates through a complex process that transforms commercial information into cultural stories relevant to the members

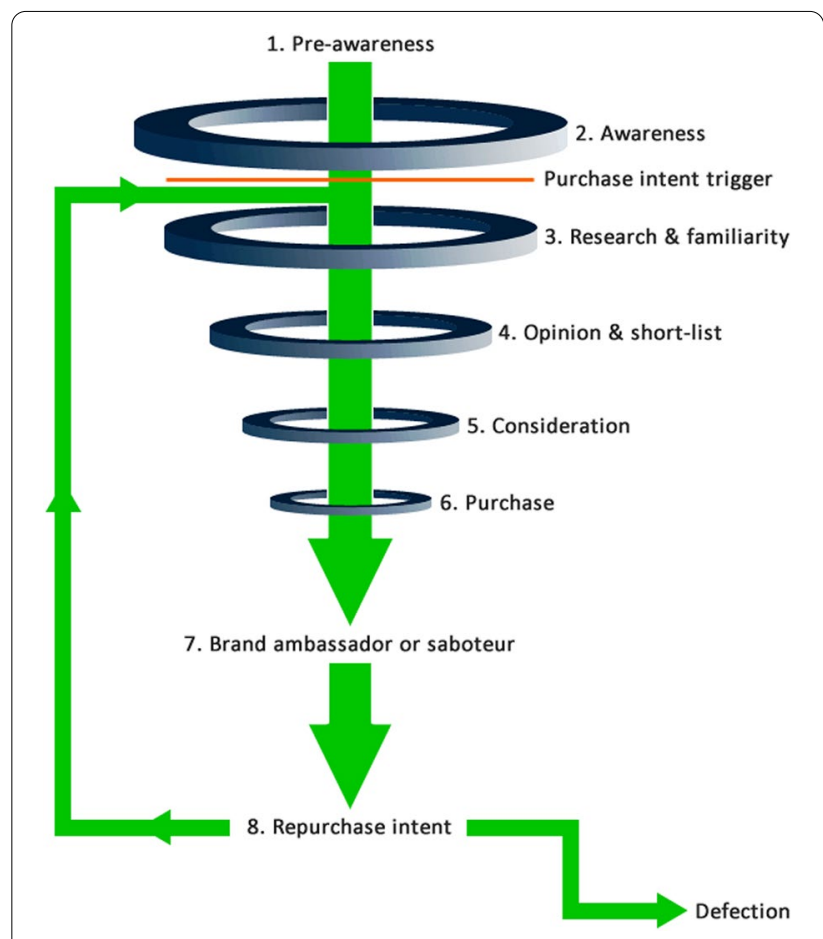

Fig. 1 Modern purchase funnel

of particular communities. The theory draws managerial attention to the importance of working with a deep knowledge and awareness of the network coproduction of marketing messages and meanings through consumergenerated narratives.

In a study by Chu and Kim [6], a conceptual framework that identified social relationship factors and their relations with eWOM in SNSs was tested. The results confirmed that tie strength, trust, normative and informational influence are positively associated with users' overall eWOM behavior on their favorite site. The article highlighted a notable difference between eWOM via social media and other online platforms such as product reviews and emails. The study suggested that product-focused eWOM in SNSs has important social implications for policy makers of social media regulation to focus on consumers who are more likely to trust their social contacts and thus engage in eWOM in SNSs.

In 2014, Moran and Muzellec [39] attempted to clarify the factors that affect the eWOM credibility. In this regard, they proposed a new framework consists of four components: community, competence, content and consensus. Thereby, they leveraged peer-to-peer users' communications in their interpersonal networks for the spreading of eWOM content. EWOM engagement on SNS was analyzed through the eWOM source and the 
eWOM message which impact the credibility of eWOM, according to their study.

Erkan and Evans [12] developed a conceptual model and highlighted the characteristics of eWOM information, such as quality and credibility of information. They predicted that the consumers who adopt eWOM information in social media are more likely to have purchase intentions and claimed that the influence of eWOM information on social media depends on the consumers' behavior toward eWOM information, as well.

In another article, they proposed the question: Is eWOM between people who knows each other on social media or eWOM between anonymous people on other online platforms more influential on consumers' online purchase intentions? They answered that anonymous reviews are more influential than friends' recommendations due to information quantity, information readiness, detailed information and dedicated information of shopping Web sites in terms of the impact of eWOM [13].

\section{Social network sites}

As defined by Kaplan and Haenlein [31], social media are "a group of internet-based applications that build on the ideological and technological foundations of Web 2.0, and that allow the creation and exchange of user generated content" [6].

Social media is the next generation of business engagement and plays a significant role in marketing. Acting in the consideration phase, social media is facilitator or disruptor of a potential purchase. Engagement, in a social business sense, means the customers are willing to take their time and energy to participate in a conversation process in the context of the social Web. The social applications connect consumers and employees with the business as a whole and facilitate the process of customer engagement [14].

Brands strive for consumer engagement on SNS in the hope of leveraging the friend connections of their followers [39]. Engagement as a business activity is conversion of the energy of customer or stakeholder passion into energy that produces a business benefit. This conversion of passion into a business benefit might occur between customers-for example, when a customer who becomes an evangelist emerges as a true advocate for your brand, product or service [14].

In the traditional communications paradigm, the elements of the promotional mix are coordinated to develop an IMC strategy, and the content, frequency, timing and medium of communications are dictated by the organization in collaboration with its paid agents [38]. The characteristics of the Internet and e-retail are: a global reach; a pull marketing approach where customers are drawn to information and purchases, rather than a push medium where customers are driven by advertising; a lack of physical contact with the goods and human contact with the sellers; a low switching cost as it takes only one click to switch between Web sites; fast and convenient; more product variety and access to viewing them; availability and accessibility irrespective of time and location; less powerful sales as it is easy to say no to a computer; and a universal appeal and uniform information [40]. If the pull marketing strategy is effective, consumers will then demand the brand from retailers [35]; so, it often creates loyal customers or followers. Social networking sites (SNSs) offer brands the ability to spread positive electronic word of mouth (eWOM) for the purposes of building awareness and acquiring new customers [39].

According to Kotler's marketing management principles, to build an effective communication, formulating each marketing message requires solving four problems: what to say (message content), how to say it logically (massage structure), how to say it imaginatively (message format) and who should say it (message source). The message content should get attention in three types of appeals: rational, emotional and moral. The massage format should be eye-catching, distinctive style in size, color and shape and movement, and body language, facial expressions, gestures, dress, posture and hairstyles of the presenter. For example, color alone can enhance message recognition for a brand [35]. As a marketing tool, color attracts consumers and can shape their perceptions. Through color, a brand can establish an effective visual identity, form strong relationships with a target market and position itself among competitors in the marketplace [37].

With regard to many-to-many communication on social media platforms that is characterized with exponential growth of the WOM volume, engagement level will be measured by: indicating interest in an existing post by pressing the "like" button or sharing the post on their profile wall or commenting on the existing post shared by the moderator or even, generating/posting content on the wall. These actions represent a form of WOM communication [8].

\section{Some previous researches on marketing through social network sites}

Mangold and Faulds [38] illustrated the impact of the interactions among consumers in the social media space on the development and execution of IMC strategies and emphasized to include social media in the promotion mix.

Hennig-Thurau et al. [22] tried to answer this question "why are consumers attracted to the new media and how do they influence consumers' affect and behavior?". They described characteristics of new media and discussed 
how they affect consumer behavior, the successful management of customer interactions and measuring customers' activities and relationship outcomes.

De Vries et al. [10] indicated that the brand post popularity drivers have strong relationship with the determinants used in advertising of a brand fan page. Hutter et al. [23] analyzed the influence of brands' social media activities and participants' social media involvement on the purchase decision-making process of consumers. Their findings demonstrated that engagement with a social network site fan page has positive effects on consumers' brand awareness, eWOM activities and purchase intention.

Soares and Pinho [46] analyzed perceived enjoyment as a predicting variable of social influence and advertising variables. The perceived enjoyment is associated with the use of online social networks that the users as members of large communities adopt group norms and develop common intentions toward advertising.

Cvijikj and Michahelles [8] measured the engagement level through number of likes over the content created by the company, number of comments and shares and also interaction duration. Their results indicated that different brand communities might have different interests and motivations for participation, resulting in different responses to characteristics of the content created by the company on brand pages, in their case, on Facebook.

At the end of literature review, it is worth mentioning the researches were done in line with issue of "social network sites marketing on luxury brands": Annie Jin [1] examined the role of consumers' hedonic motivations behind a choice behavior and their perceptions of value-expressive and social-adjustive functions of luxury brands. Their study tested the marketing potential of social media for luxury brand management. The results indicated that consumers' satisfaction with a luxury brand's social media interface is a positive predictor of favorable attitude toward the luxury brand.

Following the former researches of Kim and Ko about the impacts of social media marketing of luxury fashion brand on customer relationship and purchase intention, Kim and Ko [32] found that social media marketing activities of luxury brands comprise five constructs: entertainment, interaction, trendiness, customization and word of mouth; as value equity and brand equity affect purchase intention and social media marketing activities influence these factors, taking social media marketing into account can be a possible solution to develop relationship equity and then customer equity.

Using description of social media marketing efforts of luxury brands from five perspectives by Kim and Ko [32], Godey et al. [18] contributed that the investments in brand equity (brand awareness and brand image) whether online or off-line would strengthen social media marketing efforts on customer responses and finally convince him to pay a premium price.

The last relevant article belongs to Pentina, Guilloux and Micu [43] that analyzed social media engagement behavior of luxury consumers in 11 discrete behaviors to help luxury social media managers in monitoring social media for optimal social media marketing strategies.

\section{Conceptual Framework}

The main purpose of this study is to develop the following conceptual model theoretically and then use the examined results for identifying the impacting factors on tendency toward luxury brand with marketing approach through social network sites (see Fig. 2).

\section{Variables of the research}

As the six effective dimensions that reinforce the concept of "luxury" (1. rarity, 2. quality, 3. aesthetics, 4. symbolic meaning, 5. high level of price and 6. extraordinariness [19]) have been identified as the basis for analyzing the structural factors of social network sites such as number of likes and shares, famous followers, positive comments, form and content of marketing post, they are considered as independent variables. The demographic factors such as income level, age and marital status of potential customer are also independent variables that with regard to the mentioned features of the luxury concept could have positive or negative impact on dependent variable of "tendency toward that luxury brand."

\section{Methods}

The research method of this study is survey-descriptive in terms of data collection and is considered as applied research, in terms of purpose. The type of questionnaire is closed ended or regular and was designed according to 5-point Likert scale. The sample size was calculated as per formula: $n=\frac{Z_{\alpha}^{2} \times P Q}{e^{2}}$, and since the accurate number of individuals for investigation was not available, the error rate estimation is 0.05 . Although the calculated sample size according to the Cochran formula was 384, finally 218 valid questionnaires were obtained due to the research constraints, along with the response rate of $56.77 \%$ which could be considered as acceptable in the social sciences surveys $(R R=$ responses received/total sample) $\times 100$.

The investigated people were the inhabitants of north areas of Tehran (district nos. 1, 2 and 3) as the statistical community. They were customers of luxury brands in the mentioned districts; in order to do sampling, they were investigated in the time domain (4 months). As mentioned people were considered as social classes of $\mathrm{A}$ and 


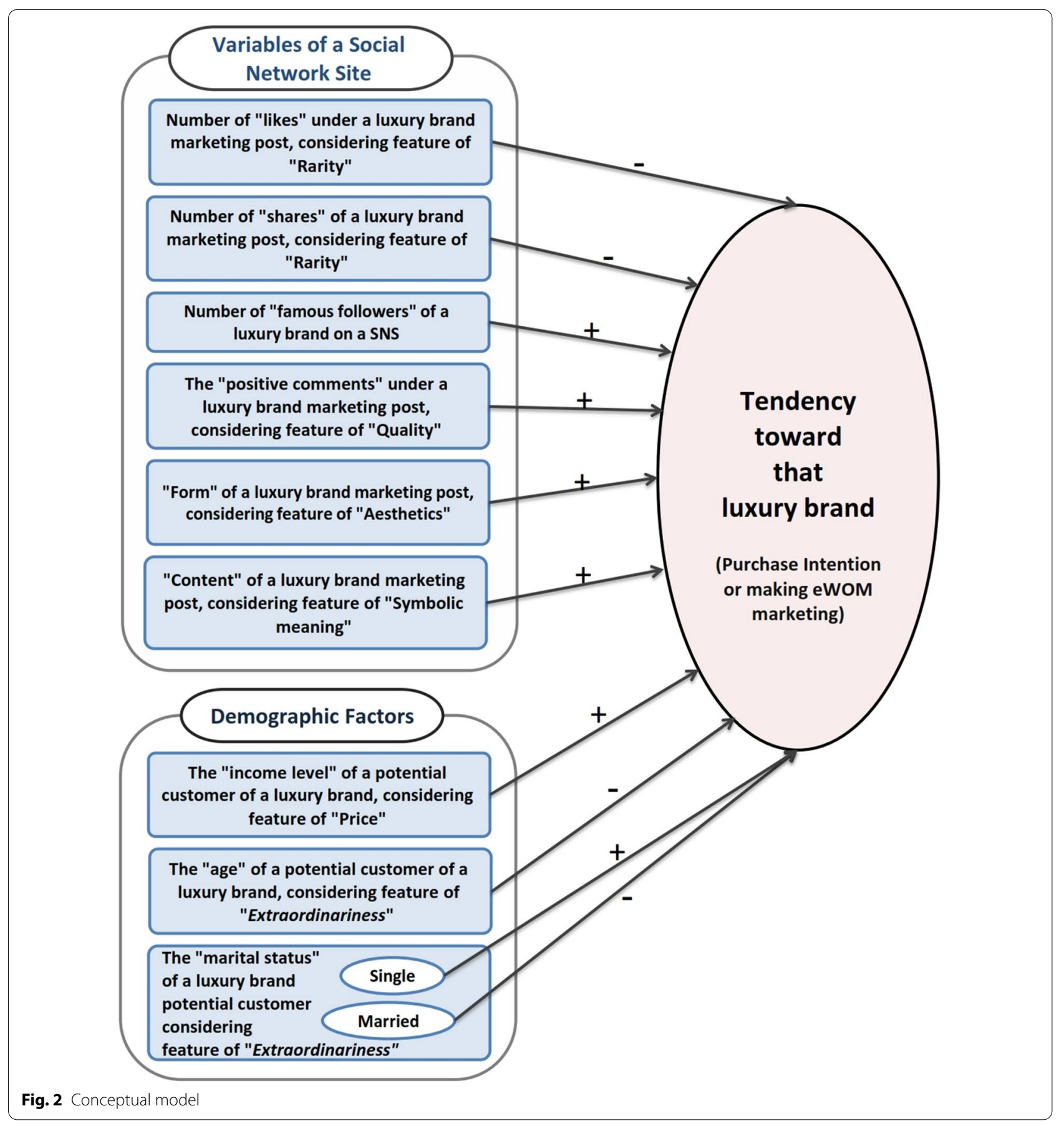

B, they pursue leisure activities like social networks sites surfing and luxury fashion brands purchasing.

In order to assess the reliability of the questionnaire, Cronbach's alpha coefficient was used that the results for the values are shown in Table 1. With regard to that the number of questions for each variable affects the measuring of Cronbach's alpha, the reliability of all variables can be considered acceptable as it is more than $70 \%$.
Confirmatory factor analysis technique was used to evaluate the construct validity of the questionnaire scale. Applying LISREL 9.1 software, the validity of each question was tested using factor load and being significant in factor loadings. After evaluation, if the factor loads of each question were greater than 0.40 and statistically significant, the question remained in the model. Figure 3 shows the factor analysis model for verifying social 


\begin{tabular}{ll}
$\begin{array}{l}\text { Table } 1 \text { Reliability by internal } \\
\text { alpha) }\end{array}$ & consistency \\
\hline Variables & $\begin{array}{l}\text { Cronbach's } \\
\text { alpha value }\end{array}$ \\
\hline Number of likes & 0.73 \\
Number of shares & 0.81 \\
Number of famous followers & 0.75 \\
Positive comments & 0.69 \\
Form of a marketing post & 0.66 \\
Content of a marketing post & 0.72 \\
\hline
\end{tabular}

network variables in the state of factor load (standardized coefficients). Considering the amounts of factor loadings obtained for the scale of social network sites questions that were greater than 0.4 and at a significance level of less than $0.01(P<0.01)$, we concluded that the validity of social network sites structure scale is verified. The range of factor loads obtained was from minimum 0.57 to maximum 0.95 (Table 2).

In order to prepare data for analysis and then test the hypotheses, the incomplete and outlier data were investigated by expectation maximization and Mahalanobis with relevant Chi-square, respectively.

\section{Results}

In this study, the extracted data were analyzed by SPSS 22 and LISREL 9.1. The results are presented in both descriptive findings and inferential findings. In the descriptive section, the demographic and main variables of research were described using frequency, percent frequency, average and standard deviations. Following skewness and kurtosis tests for the evaluation of normal distribution, for the reduction of variables to a smaller set of basic variables, the method of exploratory factor analysis through principal component analysis (PCA) was employed.

In the inferential findings and for testing research objectives, structural equation modeling technique and spearman correlation test were used. In order to examine the hypotheses, the maximum alpha error was considered $0.05(P \leq 0.05)$.

Descriptive findings shows that the percent frequency of sex of the interviewed people is $72 \%$ female and $28 \%$ male; the percent frequency of their marital status is $51 \%$ single and $49 \%$ married.

The age of studied individuals was divided into five categories: under 20 years old, 21-30, 31-40, 41-50 and more than 50 years old. The minimum percent frequency is $4 \%$ related to under the age of 20 , and the maximum is $47 \%$ which were $31-40$ years old that means nearly half of the respondents (47\%) were between 31 and 40 years old.
The percent frequency of education of the statistical population shows that most of them, which is $51 \%$ of total, had Bachelor degree among four categories. And the distribution of the percent frequency of the income of four categories indicates that the percentages are so close to each other around $23 \%$.

In order to describe the main variables statistically, the averages and standard deviations obtained are given in Table 3. The average calculation indicates that all are greater than 3 (mean value).

For checking whether the data distribution was normal or not, the skewness and kurtosis tests were performed. According to Table 4, the research variables had a normal (or near-normal) distribution because the skewness and kurtosis values of all variables were obtained at the \pm 1 range. The values indicated that the variables did not have a significant deviation from normal distribution.

The validity of the questionnaire was investigated by exploratory factor analysis. This method by reducing a large set of variables to a smaller set of basic variables called factors clarifies whether a few general factors can be identified on the basis of people's responses to the questions. Principal component analysis (PCA) was performed on 15 items of questionnaires. The orthogonal rotation was performed by varimax method.

In this study, the value of KMO measure of sampling adequacy was 0.752 (greater than 0.50 ), which indicated that about $75 \%$ of the variance of 15 items of the questionnaire was influenced by underlying factors and the factor analysis could be proceeded. As given in Table 5, the results of KMO and Bartlett's test of sphericity with significance level lower than 0.001 show that factor analysis could be considered as an appropriate technique for further data analysis.

Calculation of eigenvalues and relevant percentage of extracted variances is shown in Table 6. It confirms that those components with eigenvalue $\geq 1$ were selected. In the present research, six factors explained $75.7 \%$ of variance.

The first factor accounts for the most variance $29.9 \%$ with the highest eigenvalue. Figure 4 illustrates the number of principal components that retain in the analysis. Here, there are six factors that have eigenvalue greater than 1 . After factor 1 , there is a sharp change in the curvature of scree plot, and after factor 6 , the total variance accounts for smaller and smaller amounts.

The table 7 summarizes the final extracted factors along with relevant questions, factor loadings and the amounts of explained variance. Since the explained variance of each question was greater than 0.50 , all questions remained in the factor analysis. Also, as the factor loadings of all questions were greater than 0.30 , they were not removed from the questionnaire and each question was 


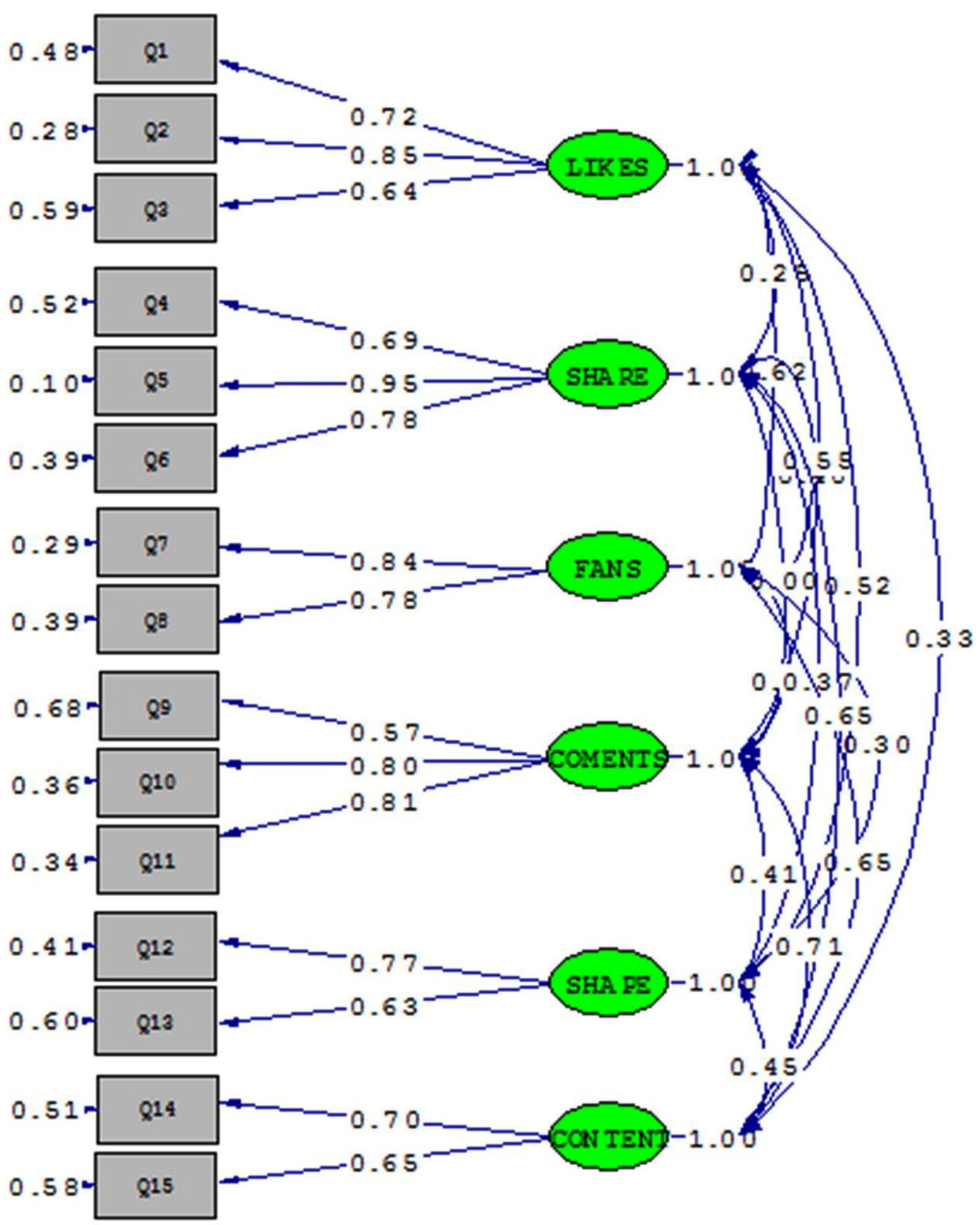

Fig. 3 Confirmatory factor analysis (CFA)

assigned to the factor that had the highest factor loadings with that factor (Table 7).

In the inferential statistics section, using the structural equation modeling technique, the research hypotheses were tested. In $T$ test issue, if $T$ value is greater than 1.96, it means that the relationship is significant at the level of less than $0.05(P<0.05)$. If it is greater than 2.58 , it means that the relationship is significant at the level less than $0.01(P<0.01)$. The research model presented in the standardized coefficient mode shows that the hypotheses are confirmed at confidence level of 99\% (Fig. 5).

Comparison of standardized coefficients shows that the strongest relationship belongs to impact of the "positive comments" under a marketing post on social network sites which affects people tendency toward luxury brands, so much (Table 8).

For model fit analysis, the determined indices: Chisquare, GFI, RMSEA and CFI, NFI, IFI as well as AGFI, 
Table 2 Factor loadings and $T$ values

\begin{tabular}{lclc}
\hline Variables & $\begin{array}{c}\text { Question } \\
\text { numbers }\end{array}$ & $\begin{array}{l}\text { Standardized } \\
\text { coefficients }\end{array}$ & $T$ values \\
\hline Number of likes & 1 & 0.72 & 11.52 \\
& 2 & 0.85 & 15.20 \\
Number of shares & 3 & 0.64 & 8.92 \\
& 4 & 0.69 & 10.11 \\
Number of famous followers/ & 7 & 0.95 & 19.26 \\
fans & 5 & 0.78 & 13.50 \\
Positive comments & 8 & 0.84 & 15.15 \\
& 9 & 0.78 & 13.68 \\
& 10 & 0.80 & 7.55 \\
Form of a marketing post & 11 & 0.81 & 13.98 \\
& 12 & 0.77 & 14.13 \\
Content of a marketing post & 13 & 0.63 & 13.06 \\
& 15 & 0.70 & 8.51 \\
& & 0.65 & 8.92 \\
\hline
\end{tabular}

Table 3 Average and standard deviation of the main variables of research

\begin{tabular}{lll}
\hline Variables & Average & $\begin{array}{l}\text { Standard } \\
\text { deviation }\end{array}$ \\
\hline Number of likes & 3.43 & 0.42 \\
Number of shares & 3.37 & 0.42 \\
Number of famous followers/fans & 4.06 & 0.62 \\
Positive comments & 3.25 & 0.37 \\
Form of a marketing post & 3.31 & 0.38 \\
Content of a marketing post & 3.51 & 0.53 \\
\hline
\end{tabular}

Table 4 Skewness and kurtosis values for the evaluation of normal distribution

\begin{tabular}{lcc}
\hline Variables & Skewness & Kurtosis \\
\hline Number of likes & -0.543 & -0.584 \\
Number of shares & -0.674 & -0.231 \\
Number of famous followers/fans & -0.474 & -0.414 \\
Positive comments & -0.110 & -0.515 \\
Form of a marketing post & 0.370 & -0.624 \\
Content of a marketing post & -0.042 & -0.066 \\
\hline
\end{tabular}

Table 5 KMO and Bartlett tests

\begin{tabular}{lll}
\hline $\begin{array}{l}\text { Kaiser-Meyer-Olkin } \\
\text { measure }\end{array}$ & \multicolumn{1}{l}{ Bartlett's test } & \\
\cline { 2 - 3 } & Approx. Chi-square & Significance level \\
\hline 0.752 & 1368.83 & $P<0.001$ \\
\hline
\end{tabular}

\begin{tabular}{|c|c|c|c|}
\hline Component & Eigenvalues & $\begin{array}{l}\text { Percentage } \\
\text { of extracted } \\
\text { variance }\end{array}$ & $\begin{array}{l}\text { Cumulative } \\
\text { percentage } \\
\text { of extracted variance }\end{array}$ \\
\hline 1 & 4.48 & 29.90 & 29.90 \\
\hline 2 & 2.03 & 13.55 & 43.45 \\
\hline 3 & 1.53 & 10.22 & 53.67 \\
\hline 4 & 1.19 & 7.95 & 61.62 \\
\hline 5 & 1.10 & 7.30 & 68.92 \\
\hline 6 & 1.01 & 6.74 & 75.66 \\
\hline
\end{tabular}

PGFI and /df Chi-square have been examined (Table 9). The only different result is seen in Chi-square value, as its sensitivity to sample size. It means the Chi-square statistic nearly always rejects the model when large samples are used; in sum, it could be concluded that the model has got a good fit.

The Spearman correlation test was done to examine the relationship between three demographic factors: income level, age and marital status and tendency toward luxury brand (Table 10). The result indicate that there is a significant relationship between the demographic factor "income level," considering feature of "price" of a luxury brand and the tendency toward luxury brand; there are no significant relationships between "age" and "marital status" of luxury brand potential customers and their tendency toward luxury brand.

\section{Discussion}

The existing luxury brand marketing literature shows that the analysis on the impact of SNS and relevant derived eWOM marketing on tendency to luxury brand, has received little benefit of theoretical investigation. The present research through collecting 218 valid questionnaires, using confirmatory factor analysis and performing PCA and structural equation modeling technique by LISREL 9.1, tested the research questions. The proposed model with appropriate fit resulted in confirmation of seven hypotheses out of nine and indicated the significant impact of social network sites with consideration the reinforcing dimensions of the concept of luxury, on tendency toward luxury brand.

With regard to the need to have a unique luxury product by a potential customer, although he/she knows well that the number of "likes" and "shares" is not as much as purchasing that product, we see a negative relationship between the number of "likes" and "shares" and tendency toward that luxury brand.

Through this study, it was found that there is a positive and significant relationship between the number 


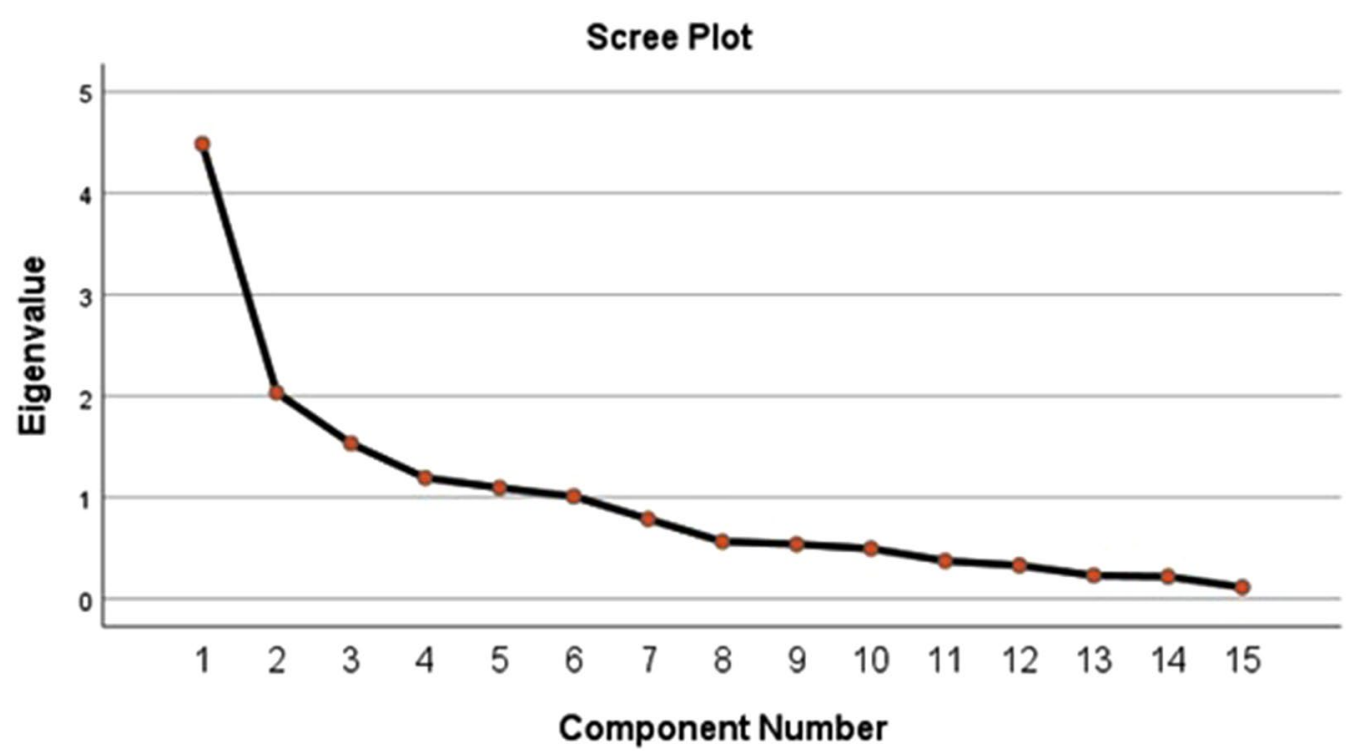

Fig. 4 Scree plot

Table 7 Extracted factors, factor loadings and explained variances

\begin{tabular}{llll}
\hline Factors & $\begin{array}{l}\text { Question } \\
\text { item }\end{array}$ & $\begin{array}{l}\text { Factor } \\
\text { loading }\end{array}$ & $\begin{array}{l}\text { Explained } \\
\text { variance }\end{array}$ \\
\hline Factor 1 (number of likes) & $\mathrm{Q} 1$ & 0.72 & 0.78 \\
& $\mathrm{Q} 2$ & 0.84 & 0.75 \\
& $\mathrm{Q} 3$ & 0.76 & 0.81 \\
Factor 2 (number of shares) & $\mathrm{Q} 4$ & 0.76 & 0.78 \\
& $\mathrm{Q} 5$ & 0.81 & 0.81 \\
Factor 3 (number of famous fol- & $\mathrm{Q} 6$ & 0.70 & 0.73 \\
lowers) & $\mathrm{Q} 7$ & 0.72 & 0.68 \\
Factor 4 (positive comments) & $\mathrm{Q} 8$ & 0.76 & 0.63 \\
& $\mathrm{Q} 9$ & 0.64 & 0.56 \\
Factor 5 (form of a marketing post) & $\mathrm{Q} 10$ & 0.79 & 0.79 \\
& $\mathrm{Q} 13$ & 0.69 & 0.61 \\
Factor 6 (content of a marketing & $\mathrm{Q} 14$ & 0.72 & 0.69 \\
post) & $\mathrm{Q} 15$ & 0.66 & 0.65 \\
\hline
\end{tabular}

of famous followers or fans of a luxury brand on social network sites and the customer's tendency toward that luxury brand. The role of celebrities and prominent individuals in new marketing strategies has been proved, whether through social network sites activities or their endorsement as advertising campaign for a brand.

Although there is not a tangible experience of the quality of a luxury product on social network sites, the customer of such brands relies on positive comments about that luxury brand which perceived by others on SNSs to get some information about the "excellent quality." So, electronic word-of-mouth marketing is spontaneously conducted through social network sites to inform people about the quality of a luxury product.

Then, there is a positive and significant relationship between the form of a luxury brand marketing post on a social network site, considering the dimension of "aesthetics" of a luxury brand and tendency toward that brand, as well as the significant effect of the content of a marketing post, regarding "symbolic meaning" feature, on the tendency of individuals to that luxury brand, due to importance of reminding the ancestral history and cultural heritage for the customer.

Among the demographic factors, the income level of a luxury brand potential customer showed a significant relationship with tendency toward that brand, considering feature of "high price" of a luxury brand. In spite of economic problems in countries like Iran, luxury brands have high demand among about $10 \%$ of population of Tehran that are considered as social classes A and B.

Finally, it was thought that the new target of luxury brand market has been changed from older customers to younger ones and many of luxury products have been designed for younger customers. We came to this conclusion that having lower age does not affect tendency toward luxury brands, and old persons have a strong tendency toward luxury brands without consideration of purchasing necessary and useful products. Also, there is not a significant relationship between "marital status" and tendency toward luxury brand. It was thought that 


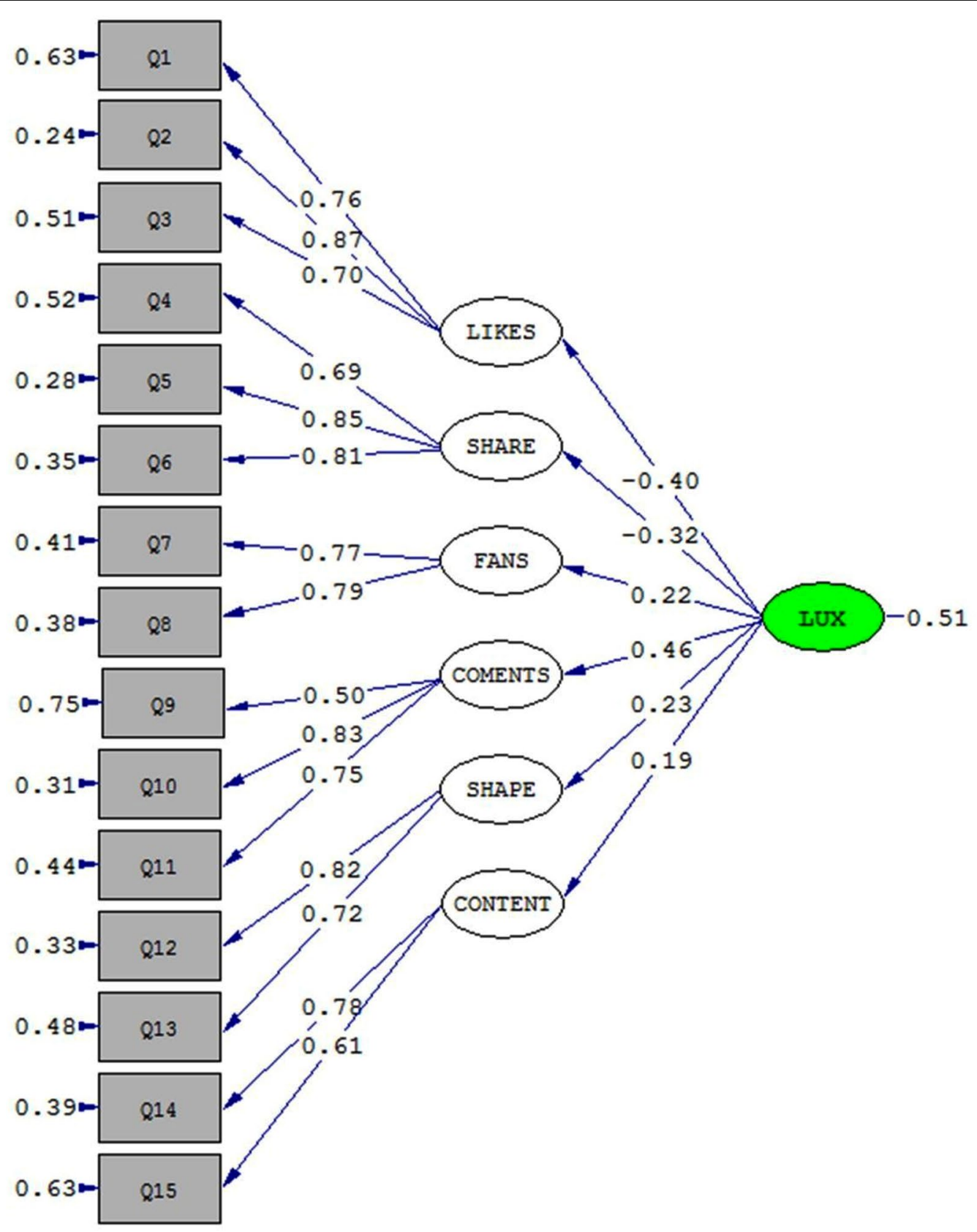

Chi-Square $=426.72, \mathrm{df}=165, \mathrm{P}-\mathrm{value}=0.00000, \mathrm{RMSEA}=0.068$

Fig. 5 Testing the conceptual model in the state of standardized estimates 
Table 8 Results of testing the model, standardized coefficients

\begin{tabular}{|c|c|c|c|}
\hline Hypothesis & $\begin{array}{l}\text { Standardized } \\
\text { coefficient }\end{array}$ & Significance level & Result of test \\
\hline Negative impact of number of likes on tendency toward luxury brand & -0.40 & $P<0.01$ & Confirmed \\
\hline Negative impact of number of shares on tendency toward luxury brand & -0.32 & $P<0.01$ & Confirmed \\
\hline Positive impact of number of famous followers/fans on tendency toward luxury brand & 0.22 & $P<0.01$ & Confirmed \\
\hline Positive impact of "positive comments" on tendency toward luxury brand & 0.46 & $P<0.01$ & Confirmed \\
\hline Positive impact of "form of a marketing post" on tendency toward luxury brand & 0.19 & $P<0.01$ & Confirmed \\
\hline Positive impact of "content of a marketing post" on tendency toward luxury brand & 0.23 & $P<0.01$ & Confirmed \\
\hline
\end{tabular}

The highest coefficient has been highlighted in italic which shows the strongest impact

Table 9 Fit indices of model

\begin{tabular}{llll}
\hline Index & Desired value & Obtained value & Description \\
\hline Chi-square & $P>0.05$ & $P<0.05$ & No fit \\
GFI & $>0.90$ & 0.93 & Good fit \\
RMSEA & $<0.08$ & 0.68 & Good fit \\
CFI & $>0.90$ & 0.92 & Good fit \\
NFI & $>0.90$ & 0.89 & Medium fit \\
IFI & $>0.90$ & 0.91 & Good fit \\
AGFI & $>0.50$ & 0.69 & Good fit \\
PGFI & $>0.50$ & 0.66 & Good fit \\
IdfChi-square & $2 \leq$ Index $\leq 3$ & 2.59 & Good fit \\
\hline
\end{tabular}

Table 10 Spearman correlation test on relationship between demographic factors and tendency to luxury brand

\begin{tabular}{lccc}
\hline Relationship & $\begin{array}{l}\text { Spearman } \\
\text { coefficient }\end{array}$ & $\begin{array}{l}\text { Significance } \\
\text { level }\end{array}$ & Result of test \\
\hline $\begin{array}{l}\text { Income level and tendency } \\
\text { toward luxury brand }\end{array}$ & 0.413 & $<0.001$ & Confirmed \\
$\begin{array}{c}\text { Age and tendency toward } \\
\text { luxury brand }\end{array}$ & -0.010 & 0.889 & Not confirmed \\
$\begin{array}{l}\text { Marital status and tendency } \\
\text { toward luxury brand }\end{array}$ & -0.105 & 0.118 & Not confirmed \\
& & & \\
\end{tabular}

being unmarried makes the potential luxury brand customer to have more tendency toward luxury brands and getting married makes couples not to purchase unnecessary products. Unexpectedly, both studied groups confirmed their tendency toward luxury brand.

\section{Conclusion}

Regarding the importance of this study, it could be useful for both researchers and luxury brand managers. From future researches perspective, the findings of this research could be developed in point of view of luxury customer behavior in social network sites or in analysis on each dimension of the luxury concept to purchase intention of a luxury brand. The results of this research could be used to examine the impact of social media marketing to luxury items in specific segment of this industry such as hotels and restaurants. By implementing the findings of this study, luxury brand managers through emphasizing on marketing "communication" mix, specially through social network sites, could achieve competitive advantage and maintain their strong relationship with their customers. They could rely on these results when seeking to address existing and new target groups.

Although there were some theoretical and practical limitations during performing this research, one of them that is worth mentioning, was the lack of cooperation in filling out the questionnaires by luxury brand customers in statistical population, correctly. So, in order to raise the validity of the questionnaire, the researchers could only design the questions in a way that the answers could be compared.

\section{Abbreviations}

CFA: Confirmatory factor analysis; eWOM: electronic word of mouth; IMC: Integrated marketing communication; KMO: Kaiser-Meyer-Olkin; PCA: Principal component analysis; ROPO: Research online and purchase off-line; SNS: Social network sites; WOM: Word of mouth.

\section{Acknowledgements}

The submitted document is the result of a research for master thesis, done by the corresponding author under supervision of the other author.

\section{Authors' contributions}

We certify that we have participated sufficiently in the work. Both authors read and approved the final manuscript.

\section{Funding}

No funding was received for conducting of this study.

\section{Availability of data and materials}

All data generated or analyzed during this study are included in this published article [and its additional files].

\section{Competing interests}

The authors declare that they have no competing interests.

\section{Author details}

${ }^{1}$ Faculty of Management, Economics and Accountancy, Payame Noor University, Karaj, Alborz, Iran. ${ }^{2}$ Higher Education Centre for Cultural Heritage, Tehran, Iran. 


\section{Appendix}

\section{Questionnaire}

Dear Respondent

Hereby, you are kindly requested to assist us by completing this questionnaire which is related to a research study on Analysis of the impact of social network sites and eWOM marketing, considering the reinforcing dimensions of the concept of luxury, on tendency toward luxury brand.

Your participation of this study is voluntary and will not take more than 15 minutes of your time.

Thank you in advance.

\section{Demographic questions}

Gender: Female $\square \quad$ Male $\square$

Age: under 20-year-old $\square \quad 21-30 \square \quad 31-40 \square \quad 41-50 \square \quad$ more than 50 years old $\square$

Education: Diploma degree $\square \quad$ Bachelor's degree $\square \quad$ Master's degree $\square \quad$ Doctorate $\square$

Income level: Less than 5 million Toman $\square \quad 5 \mathrm{~m}-10 \mathrm{~m} \square \quad 10 \mathrm{~m}-15 \mathrm{~m} \square \quad$ more than 15 million Toman $\square$

Marital Status: Single $\square$ Married $\square$

\section{Principal questions}

1) When I encounter a luxury brand marketing post on a SNS with high number of likes under it, I feel hesitating and uncertain about the rarity and infrequency of relevant luxury product and it makes me not to have a tendency to that brand.

$$
\begin{gathered}
\text { Strongly agree } \square \quad \text { Agree } \square \\
\text { Neutral } \square
\end{gathered}
$$

Strongly disagree $\square \quad$ Disagree $\square$

2) When I encounter a luxury brand marketing post on a SNS with low number of likes under it, I feel that I have a tendency to purchase relevant product or express my attitude as a positive comment.

Strongly agree $\square \quad$ Agree $\square$
Neutral $\square$

Strongly disagree $\square \quad$ Disagree $\square$

3) The number of likes under a luxury brand marketing post on a SNS, does not have any impact on my tendency toward that luxury brand.

Strongly agree $\square \quad$ Agree $\square$
Neutral $\square$

4) When I encounter high number of shared posts of a luxury brand, I feel hesitating and uncertain about the rarity and uniqueness of relevant luxury product and it makes me not to have a tendency toward it.

Strongly disagree $\square \quad$ Disagree $\square$

Strongly agree $\square \quad$ Agree $\square$
Neutral $\square$

Strongly disagree $\square \quad$ Disagree $\square$ 


\begin{tabular}{|c|c|c|}
\hline \multirow{2}{*}{$\begin{array}{l}\text { 5) Low number of shared posts of a luxury brand makes me } \\
\text { have a tendency toward it and I arrange to purchase relevant } \\
\text { product or express my attitude as a positive comment. }\end{array}$} & \multicolumn{2}{|l|}{$\begin{array}{l}\text { Strongly agree } \square \\
\text { Neutral } \square\end{array}$} \\
\hline & Strongly disagree $\square$ & Disagree $\square$ \\
\hline \multirow{3}{*}{$\begin{array}{l}\text { 6) I don't care about the number of shares of a luxury brand } \\
\text { marketing post because it doesn't represent the number of real } \\
\text { purchaser of that luxury brand. }\end{array}$} & Strongly agree $\square$ & Agree $\square$ \\
\hline & Neutral $\square$ & \\
\hline & Strongly disagree $\square$ & Disagree $\square$ \\
\hline \multirow{3}{*}{$\begin{array}{l}\text { 7) After visiting the pages of luxury brands on SNSs and } \\
\text { noticing of the number of famous followers of the luxury } \\
\text { brands, I feel affected and tend to purchase the product or } \\
\text { demonstrate my attitude by commenting, in a positive way. }\end{array}$} & Strongly agree $\square$ & Agree $\square$ \\
\hline & Neutral $\square$ & \\
\hline & Strongly disagree $\square$ & Disagree $\square$ \\
\hline \multirow{3}{*}{$\begin{array}{l}\text { 8) Generally, I feel inclined to a luxury brand while } \\
\text { encountering a luxury brand marketing post has been } \\
\text { endorsed/supported by famous person/celebrity. }\end{array}$} & Strongly agree $\square$ & Agree $\square$ \\
\hline & Neutral $\square$ & \\
\hline & Strongly disagree $\square$ & Disagree $\square$ \\
\hline \multirow{3}{*}{$\begin{array}{l}\text { 9) When I find my friends' positive comments under a luxury } \\
\text { brand marketing post on a SNS, I feel sure of the quality of } \\
\text { the luxury product and arrange to purchase it or express my } \\
\text { attitude a positive comment. }\end{array}$} & Strongly agree $\square$ & Agree $\square$ \\
\hline & Neut & \\
\hline & Strongly disagree $\square$ & Disagree $\square$ \\
\hline \multirow{3}{*}{$\begin{array}{l}\text { 10) I don't take any notice to positive comments under a } \\
\text { luxury brand marketing post because I believe that the quality } \\
\text { of a luxury product cannot be perceived by relying on } \\
\text { comments/Word-Of-Mouth. }\end{array}$} & Strongly agree $\square$ & Agree $\square$ \\
\hline & Neutral $\square$ & \\
\hline & Strongly disagree $\square$ & Disagree $\square$ \\
\hline \multirow{3}{*}{$\begin{array}{l}\text { 11) Negative comments under a luxury brand marketing post } \\
\text { have significant impact on my disinclination toward that } \\
\text { luxury brand. }\end{array}$} & Strongly agree $\square$ & Agree $\square$ \\
\hline & Neutral $\square$ & \\
\hline & Strongly disagree $\square$ & Disagree $\square$ \\
\hline \multirow{3}{*}{$\begin{array}{l}\text { 12) When I encounter a luxury brand marketing post that has } \\
\text { been designed beautifully and dazzlingly, I feel that I have a } \\
\text { tendency toward that luxury brand. }\end{array}$} & Strongly agree $\square$ & Agree $\square$ \\
\hline & Neutral $\square$ & \\
\hline & Strongly disagree $\square$ & Disagree $\square$ \\
\hline \multirow{3}{*}{$\begin{array}{l}\text { 13) The harsh and unpleasant marketing post of a luxury } \\
\text { brand, have a negative impact on my attitude toward it. } \\
\text { Because of the importance of aesthetic dimension of this type } \\
\text { of brands, even in relevant marketing post. }\end{array}$} & Strongly & Agree $\square$ \\
\hline & $\mathrm{Neu}$ & \\
\hline & Strongly disagree $\square$ & Disagree $\square$ \\
\hline \multirow{3}{*}{$\begin{array}{l}\text { 14) When I encounter a luxury brand marketing post that is } \\
\text { stating any symbolic meaning or our ancestral heritage, I feel } \\
\text { connected with that brand and demonstrate my tendency by } \\
\text { purchasing relevant product or expressing my positive } \\
\text { attitude through commenting. }\end{array}$} & Strongly agr & Agree $\square$ \\
\hline & al $\square$ & \\
\hline & Strongly disagree $\square$ & Disagree $\square$ \\
\hline \multirow{3}{*}{$\begin{array}{l}\text { 15) In case of noticing that a luxury marketing post doesn't } \\
\text { have any sign of symbolic meaning, I don't feel having } \\
\text { tendency toward that luxury brand. }\end{array}$} & Strongly agree $\square$ & Agree $\square$ \\
\hline & Neutral $\square$ & \\
\hline & Strongly disagree $\square$ & Disagree $\square$ \\
\hline
\end{tabular}




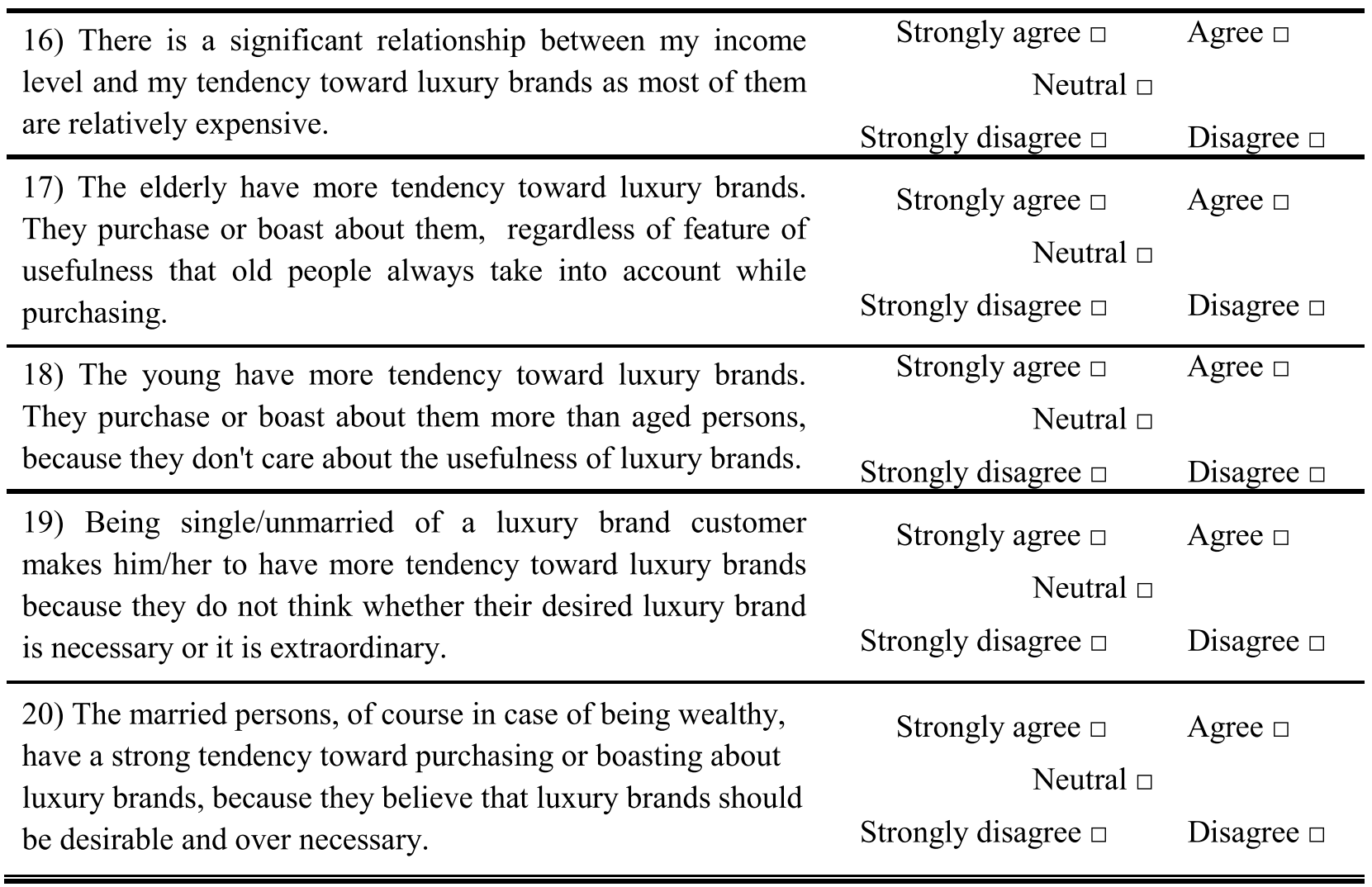

Received: 14 December 2019 Accepted: 28 February 2020

Published: 11 June 2020

\section{References}

1. Annie Jin SA (2012) The potential of social media for luxury brand management. Mark Intell Plan 30(7):687-699

2. Bastien V, Kapferer J-N (2013) More on luxury anti-laws of marketing. In: Wiedmann KP, Hennigs N (eds) Luxury Marketing. Gabler Verlag, Wiesbaden, pp 19-34

3. Batat W (2019) The new luxury experience. Springer, Berlin

4. Bilge HA (2015) Luxury consumption: literature review. Khazar J of Humanities and Social Sciences. https://doi. org/10.5782/2223-2621.2014.18.1.35

5. Chen Y, Fay S, Wang Q (2011) The role of marketing in social media: how online consumer reviews evolve. J Interact Mark 25(2):85-94

6. Chu S-C, Kim Y (2011) Determinants of consumer engagement in electronic word-of-mouth (eWOM) in social networking sites. Int J Advert 30(1):47-75

7. Cuomo MT, Foroudi P, Tortora D, Hussain S, Melewar T (2019) Celebrity endorsement and the attitude towards luxury brands for sustainable consumption. Sustainability 11(23):6791

8. Cvijikj IP, Michahelles F (2013) Online engagement factors on Facebook brand pages. Soc Netw Anal 3(4):843-861

9. De Bruyn A, Lilien GL (2008) A multi-stage model of word-of-mouth influence through viral marketing. Int J Res Mark 25(3):151-163

10. De Vries L, Gensler S, Leeflang PS (2012) Popularity of brand posts on brand fan pages: an investigation of the effects of social media marketing. J Interact Mark 26(2):83-91
11. Dubois B, Laurent G, Czellar S (2001) Consumer rapport to luxury: analyzing complex and ambivalent attitudes, vol 736. Groupe HEC, Jouy-en-Josas

12. Erkan I, Evans C (2016) The influence of eWOM in social media on consumers' purchase intentions: an extended approach to information adoption. Comput Hum Behav 61:47-55

13. Erkan I, Evans C (2018) Social media or shopping websites? The influence of eWOM on consumers' online purchase intentions. J Mark Commun 24(6):617-632

14. Evans D (2010) Social media marketing: an hour a day. Wiley, New York

15. Fionda AM, Moore CM (2009) The anatomy of the luxury fashion brand. J Brand Manag 16(5-6):347-363

16. Freire NA (2014) When luxury advertising adds the identitary values of luxury: a semiotic analysis. J Bus Res 67(12):2666-2675

17. Gibson J (2017) Purchase funnel—definition and introduction. Retrieved February 07, 2018, from http://marketing-made-simple.com

18. Godey B, Manthiou A, Pederzoli D, Rokka J, Aiello G, Donvito R, Singh $R$ (2016) Social media marketing efforts of luxury brands: influence on brand equity and consumer behavior. J Bus Res 69(12):5833-5841

19. Heine K (2012) The concept of luxury brands. Luxury Brand Management, Berlin

20. Heine K, Phan M (2011) Trading-up mass-market goods to luxury products. Austr Mark J 19(2):108-114

21. Hennig-Thurau T, Gwinner KP, Walsh G, Gremler DD (2004) Electronic word-of-mouth via consumer-opinion platforms: what motivates consumers to articulate themselves on the Internet? J Interact Mark 18(1):38-52

22. Hennig-Thurau T, Malthouse EC, Friege C, Gensler S, Lobschat L, Rangaswamy A, Skiera B (2010) The impact of new media on customer relationships. J Serv Res 13(3):311-330 
23. Hutter K, Hautz J, Dennhardt S, Füller J (2013) The impact of user interactions in social media on brand awareness and purchase intention: the case of MINI on Facebook. J Prod Brand Manag 22(5/6):342-351

24. Jahn B, Kunz W, Meyer A (2012) The role of social media for luxury brand-motives for consumer engagement and opportunities for business. In: Burmann C, König V, Meurer J (eds) Identitätsbasierte Luxusmarkenführung. Springer Gabler, Wiesbaden, pp 221-236

25. Joy A, Wang JJ, Chan T-S, Sherry JF Jr, Cui G (2014) M (Art) worlds: consumer perceptions of how luxury brand stores become art institutions. $J$ Retail 90(3):347-364

26. Jung Choo H, Moon H, Kim H, Yoon N (2012) Luxury customer value. J Fashion Mark Manag Int J 16(1):81-101

27. Kapferer J-N (2012) Abundant rarity: the key to luxury growth. Bus Horiz 55(5):453-462

28. Kapferer J-N, Bastien V (2009) The specificity of luxury management: turning marketing upside down. J Brand Manag 16(5-6):311-322

29. Kapferer J-N, Bastien V (2012) The luxury strategy: break the rules of marketing to build luxury brands. Kogan page publishers, London

30. Kapferer J-N, Laurent G (2016) Where do consumers think luxury begins? A study of perceived minimum price for 21 luxury goods in 7 countries. J Bus Res 69(1):332-340

31. Kaplan AM, Haenlein M (2010) Users of the world, unite! The challenges and opportunities of Social Media. Bus Horiz 53(1):59-68

32. Kim AJ, Ko E (2012) Do social media marketing activities enhance customer equity? An empirical study of luxury fashion brand. J Bus Res 65(10):1480-1486

33. Klein JF, FalkT, Esch F-R, Gloukhovtsev A (2016) Linking pop-up brand stores to brand experience and word of mouth: the case of luxury retail. J Bus Res 69(12):5761-5767

34. Koronaki E, Kyrousi AG, Panigyrakis GG (2018) The emotional value of artsbased initiatives: strengthening the luxury brand-consumer relationship. J Bus Res 85:406-413

35. Kotler P, Armstrong G (2012) Principles of marketing, 14th edn. Pearson Education Limited, London

36. Kozinets RV, De Valck K, Wojnicki AC, Wilner SJ (2010) Networked narratives: understanding word-of-mouth marketing in online communities. J Mark 74(2):71-89

37. Labrecque LI, Milne GR (2012) Exciting red and competent blue: the importance of color in marketing. J Acad Mark Sci 40(5):711-727

38. Mangold WG, Faulds DJ (2009) Social media: the new hybrid element of the promotion mix. Bus Horiz 52(4):357-365
39. Moran G, Muzellec LJ (2017) eWOM credibility on social networking sites: a framework. J Mark Commun 23(2):149-161

40. Okonkwo U (2009) Sustaining the luxury brand on the Internet. J Brand Manag 16(5-6):302-310

41. Okonkwo U (2010) Luxury online: styles, systems, strategies. Springer, Berlin

42. Parguel B, Delécolle T, Valette-Florence P (2016) How price display influences consumer luxury perceptions. J Bus Res 69(1):341-348

43. Pentina I, Guilloux V, Micu AC (2018) Exploring social media engagement behaviors in the context of luxury brands. J Advert 47(1):55-69

44. Shimul AS, Phau I (2018) Consumer advocacy for luxury brands. Aust Mark J 26(3):264-271

45. Shukla P, Banerjee M, Singh J (2016) Customer commitment to luxury brands: antecedents and consequences. J Bus Res 69(1):323-331

46. Soares AM, Pinho JC (2014) Advertising in online social networks: the role of perceived enjoyment and social influence. J Res Interact Mark $8(3): 245-263$

47. Sudarsan S (2013) Luxury brand Management. Retrieved October 11, 2018, from https://www.slideshare.net/SudioSudarsan/luxury-brand -management/18-Kotler_Philip_Dierentiation_of_Products

48. Turunen LLM (2018) Concept of luxury through the lens of history. In: Interpretations of luxury. Springer, Berlin, pp 13-29

49. Voitehina A (2018) How to build a sales funnel for B2B model. Retrieved August 08, 2019, https://cience.com/how-to-build-a-sales-funne I-for-b2b-model

50. Wiedmann K-P, Hennigs N (2013) Placing luxury marketing on the research agenda not only for the sake of luxury - an introduction. In: Wiedmann KP, Hennigs N (eds) Luxury Marketing. Gabler Verlag, Wiesbaden, pp 3-17

51. Wiedmann K-P, Hennigs N, Siebels A (2007) Measuring consumers' luxury value perception: a cross-cultural framework. Acad Mark Sci Rev 7:1-21

\section{Publisher's Note}

Springer Nature remains neutral with regard to jurisdictional claims in published maps and institutional affiliations.

\section{Submit your manuscript to a SpringerOpen ${ }^{\circ}$ journal and benefit from:}

- Convenient online submission

- Rigorous peer review

- Open access: articles freely available online

- High visibility within the field

- Retaining the copyright to your article

Submit your next manuscript at springeropen.com 